\title{
EFEK PERBEDAAN KONSENTRASI Smilax $S p$ TERHADAP EDEMI PADA Femur Gallus gallus domesticus
}

\author{
Ferlin M Mandaku ${ }^{1}$, Aung Sumbono ${ }^{2.3}$, Ratna Prabawati ${ }^{1}$ \\ ${ }^{1}$ Program Studi Pendidikan Biologi UNIMUDA Sorong \\ ${ }^{2}$ LP3M UNIMUDA Sorong \\ ${ }^{3}$ Program Studi Farmasi UNIMUDA Sorong
}

\author{
mandaku06@gmail.com
}

\begin{abstract}
ABSTRAK
Penelitian ini untuk mengetahui efek konsentrasi Smilax $S p$ terhadap edemi pada Femur Gallus gallus domesticus $(F g g)$. Metode yang dipakai adalah eksperimen menggunakan instrumen observasi, dokumentasi, mikroskop dan alat ukur. Tempat penelitian Laboratorium Terpadu UNIMUDA Sorong. Sampel yang digunakan ialah daun Smilax Sp masih segar dengan tingkat konsentrasi 5 gr, 10 gr, 15 gr, 25 gr, 30 gr, 40 gr, 45 gr, 55 gr, 60 gr, 65 gr, 70 gr, 75 gr, 80 gr, 85 gr, 90 gr, 95 gr dan Fgg berumur 1 bulan 17 ekor. Teknik analisis data yang digunakan ialah perbandingan dan persentase. Hasil penelitian dapat disimpulkan bahwa aktivitas Smilax Sp dapat menyebabkan edemi pada Fgg, Perbedaan konsentrasi Smilax Sp menyebabkan tingkat perubahan edemi bervariasi pasang surut sehingga semakin tinggi tingkat konsentrasi yang diberikan maka semakin besar pula efek yang terjadi. Terjadi perubahan warna kulit dengan kode warna B22222, berkerut, penumpukan lemak pada permukaan bagian atas, pori - pori menjadi lebih besar, iritasi hingga terjadi pemecahan pembuluh darah, terdapat cairan dengan kode warna FFFFE0 yang keluar dari jaringan subkutannya serta terjadi sedikit perubahan warna (kode warna FAFAD2) pada daging. Persentase edemi massa tertingginya sebesar 41,66\%, keliling 66,67\%, tebal $400 \%$ dan lebar $175 \%$.
\end{abstract}

Kata Kunci : Edemi, Konsentrasi, Smilax $S p$

\section{ABSTRACT}

This research is to find out the effect of Smilax Sp concentration on edema in Femur Gallus gallus domesticus (Fgg). The method used was an experiment using observation instruments, documentation, microscopy and measuring instruments. The place of research the Laboratory Integrated of UNIMUDA Sorong. The sample used was fresh Smilax Sp leaves with a concentration level of $5 \mathrm{gr}, 10 \mathrm{gr}, 15 \mathrm{gr}, 25 \mathrm{gr}, 30 \mathrm{gr}, 40 \mathrm{gr}, 45 \mathrm{gr}, 55 \mathrm{gr}, 60$ $\mathrm{gr}, 65 \mathrm{gr}, 70 \mathrm{gr}, 75 \mathrm{gr}, 80 \mathrm{gr}, 85 \mathrm{gr}, 90 \mathrm{gr}, 95 \mathrm{gr}$ and Fgg 1 month 17 tails. The data analysis technique used is comparison and percentage. The results of the study can be concluded that the activity of Smilax Sp can cause edema in Fgg, the difference in Smilax Sp concentration causes the level of edema changes varies tides so that the higher the level of concentration given the greater the effect will occur. Changes in skin color with a color code B22222, wrinkling, accumulation of fat on the upper surface, pores become larger, irritation to blood vessel breakdown, there is a liquid with color code FFFFEO that comes out of the subcutaneous tissue and there is a slight change in color (code color FAFAD2) on meat. The highest percentage mass of edema was $41.66 \%$, circumference $66.67 \%$, thickness $400 \%$ and width $175 \%$.

Keywords:Edema, Concentration, Smilax Sp

\section{PENDAHULUAN}

Sejak zaman prasejarah, manusia telah menggunakan produk alami, seperti tanaman, hewan, mikroorganisme, dan organisme laut, dalam obatobatan untuk meringankan dan mengobati berbagai macam penyakit (1). Namun yang paling dominan dari semua produk alami tersebut adalah tanaman karena menurut catatan fosil penggunaan tanaman oleh manusia sebagai salah satu sumber obat tradisional telah dilakukan selama kurang lebih 60.000 tahun (2). Penggunaan tanaman sebagai salah satu sumber obat tradisional yang bertujuan untuk penyembuhan secara alami juga membentuk asal mula dari adanya pengobatan modern (3).

Hingga saat ini penggunaan obat tradisional yang berasal dari tanaman masih menjadi yang terbaik dan mendapat posisi sekitar $75-80 \%$ dalam populasi dunia terutama di Negara berkembang karena masyarakat percaya bahwa obat tradisional terutama yang bersumber dari tanaman cenderung memiliki efek samping yang lebih rendah, murah dan ketersediaannya secara lokal (4). Selain itu komposisi yang ada pada obat tradisional tergantung pada beberapa faktor seperti bagian anatomi tanaman yang digunakan, misalnya (biji, daun, bunga, akar dan lain sebagainya) dan juga tempat penyimpanannya, intensitas cahaya matahari, kelembaban, jenis tanah, waktu panen, area geografis serta konsentrasinya (5).

Salah satu Negara yang termasuk dalam kategori Negara berkembang adalah Negara Indonesia dengan tingkat keanekaragaman hayati terutama keanekaragaman spesies tumbuhan dan ekosistemnya yang sangat tinggi karena tercatat hingga saat ini Negara Indonesia memiliki sebanyak $39 \%$ tumbuhan endemik yang tersebar di berbagai daerah (6). Sumber 
penghasilan tumbuhan endemik di Indonesia salah satunya terdapat di pulau Papua dengan kekayaan hutannya yang menyimpan sekitar $20.000-25.000$ jenis tumbuhan (7) dan 50 - 90\% termasuk dalam kategori tumbuhan endemik yang dapat dijadikan sebagai sumber bahan obat - obatan tradisional (8). Namun, hingga saat ini hutan Papua belum banyak di eksplorasi sebagai sumber bahan obat-obatan tradisional oleh masyarakat khususnya yang ada di pulau Papua.

Beberapa riset memang telah dilakukan terhadap berbagai spesies tanaman asli dari hutan Papua yang dapat dijadikan sebagai sumber bahan obat - obatan seperti salah satunya yaitu tanaman buah merah (Pandanus conoideus Lam) yang berkhasiat untuk mengobati penyakit diabetes mellitus, jantung koroner, hipertensi bahkan berperan dalam pencegahan penyebaran virus penyakit HIV/AIDS (9). Akan tetapi tanaman asli milik hutan Papua yang dapat dijadikan sebagai sumber bahan obat - obatan tradisional bukan hanya tanaman buah merah (Pandanus conoideus Lam), namun ada juga tanaman daun tiga jari (Smilax $S p$ ) atau masyarakat Papua biasa menyebutnya dalam bahasa lokal dengan istilah daun bungkus yang digunakan pada umumnya untuk memperbesar alat kelamin pria melalui proses pembengkakan atau edemi.

Smilax merupakan salah satu genus tanaman yang termasuk dalam kelompok tanaman monokotil dan termasuk dalam keluarga Smilacaceae serta terdiri dari sekitar 300-350 jenis yang tersebar di berbagai Negara di dunia (10). Beberapa jenis Smilax memang telah digunakan sebagai sumber bahan obat-obatan tradisional untuk mengobati berbagai macam penyakit, salah satunya adalah Smilax Aspera yang digunakan untuk mengobati penyakit sifilis, rematik, diabetes dan sebagai antioksidan untuk mengurangi ketidaknyamanan menopause (11). Akan tetapi penggunaan berbagai jenis tanaman Smilax sebagai sumber bahan obat-obatan tradisional tentunya tidak terlepas dari konsentrasi dan juga efek samping dari tanaman Smilax tersebut.

Berbagai penelitian juga telah dilakukan terhadap beberapa jenis tanaman Smilax seperti Analisis Fitokimia Awal, Antimikroba dan Anti oksidan Aktivitas Smilax Zeylanica L. (12), Senyawa Fenolik pada Genus Smilax Sarsaparilla (13), Smilax dari Miocene Western Eurasia dengan Affinitas Biogeografi Karibia (14), Analisis Filogenetik dan Identifikasi Molekuler Canar Smilax Spp di Jawa, Indonesia berdasarkan Analisis Kode Batang DNA

(15) serta Identifikasi Proses Edemi Efek dari Smilax $S p$ (16). Namun dari beberapa penelitian tentang tanaman Smilax tersebut belum ada penelitian yang berkaitan dengan konsentrasi penggunaan tanaman Smilax terutama tanaman Smilax Sp sebagai salah satu sumber bahan obat-obatan tradisional, oleh karena hal tersebut maka perlu dilakukan riset/kajian tentang konsentrasi penggunaan tanaman Smilax Sp sebagai salah satu sumber bahan obat-obatan tradisional.

\section{METODE PENELITIAN}

Pendekatan yang dipakai dalam peneltian ini adalah penelitian eksperimen. Penelitian eksperimen merupakan penelitian yang dilakukan dengan cara memanipulasi minimal satu variabel untuk mempelajari hubungan sebab akibat sehingga dapat menguji suatu hipotesis dalam rangka mencari pengaruh, hubungan, maupun perbedaan perubahan terhadap kelompok yang dikenakan perlakuan (17).

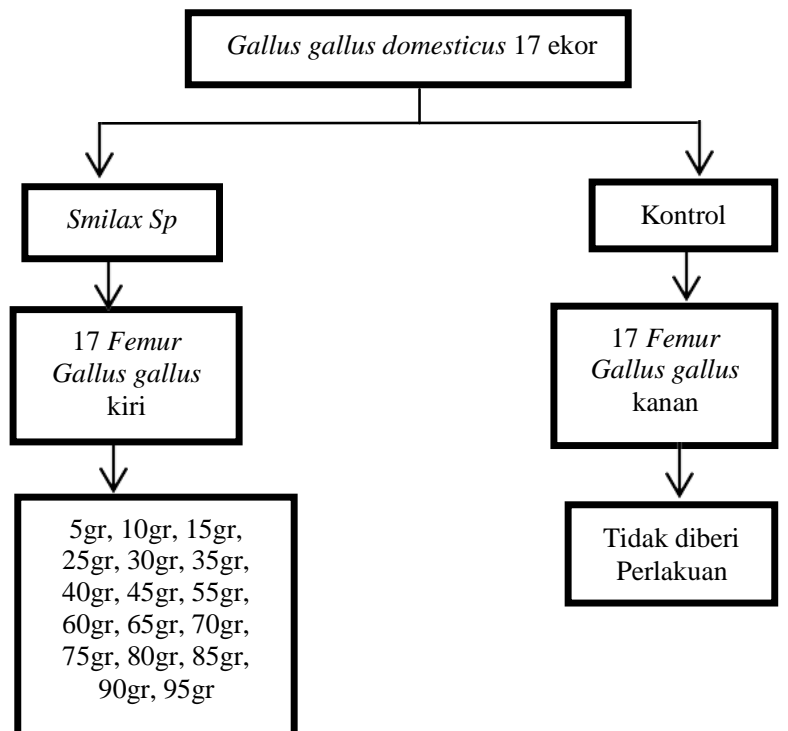

Gambar 2-1 Skema Penelitian

Penelitian dilaksanakan pada tanggal 22 Februari - 22 Maret 2020, yang bertempat di Laboratorium Terpadu Universitas Pendidikan Muhammadiyah Sorong. Populasi dalam penelitian ini yaitu semua tanaman obat tradisional dan semua hewan yang ada di Kabupaten Sorong. Sampel dalam penelitian ini yaitu tanaman Smilax Sp yang diperoleh dari Jl. Mariyat Pantai, Kelurahan Mariyat Pantai Distrik Aimas dan Gallus gallus domesticus yang diperoleh dari Jl. Kontener Kabupaten Sorong sebanyak 17 ekor berumur 1 bulan dan berjenis kelamin jantan serta memiliki berat yang berkisar antara $1,3-1,5 \mathrm{~kg}$. Bagian Smilax $S p$ yang dipakai adalah daun segar yang baru dipetik dan bagian Gallus gallus domesticus yang dipakai sebagai sampel adalah Femur Gallus gallus domesticus. Alat - alat yang digunakan dalam penelitian ini adalah sebagai berikut timbangan analitik, nampan, gunting bedah/biasa, pisau, mortal dan pastle, pisau, jangka sorong, spatula, tabel warna, mikroskop, kamera, ember, kain kasa, perban, instrumen penelitian, pena, spidol, sarung tangan dan masker. Bahan-bahan yang digunakan dalam penelitian ini adalah sebagai berikut : air bersih, daun Smilax Sp, Hewan Gallus gallus domesticus. Teknik pengumpulan data yang digunakan dalam penelitian ini adalah sebagai berikut observasi, dokumentasi, mikroskop dan alat ukur. Teknik analisis data yang akan dilakukan dalam penelitian ini yaitu deskripsi dan persentase. 


\section{PEMBAHASAN}

Data hasil, selisih dan peresentase massa, keliling, tebal, lebar dan tingkat perubahan yang terjadi pada Fgg akan ditampilkan pada gambar 3.1 hingga 3.13 .

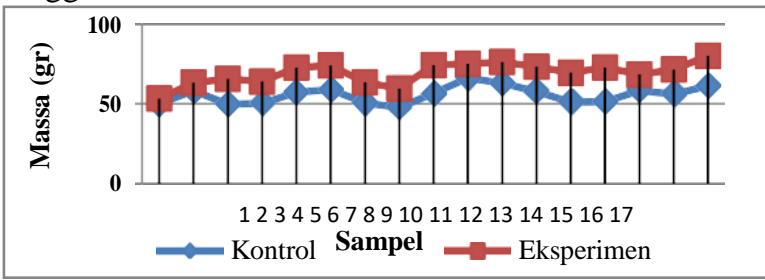

Gambar 3-1 Grafik Data Hasil Massa Fgg

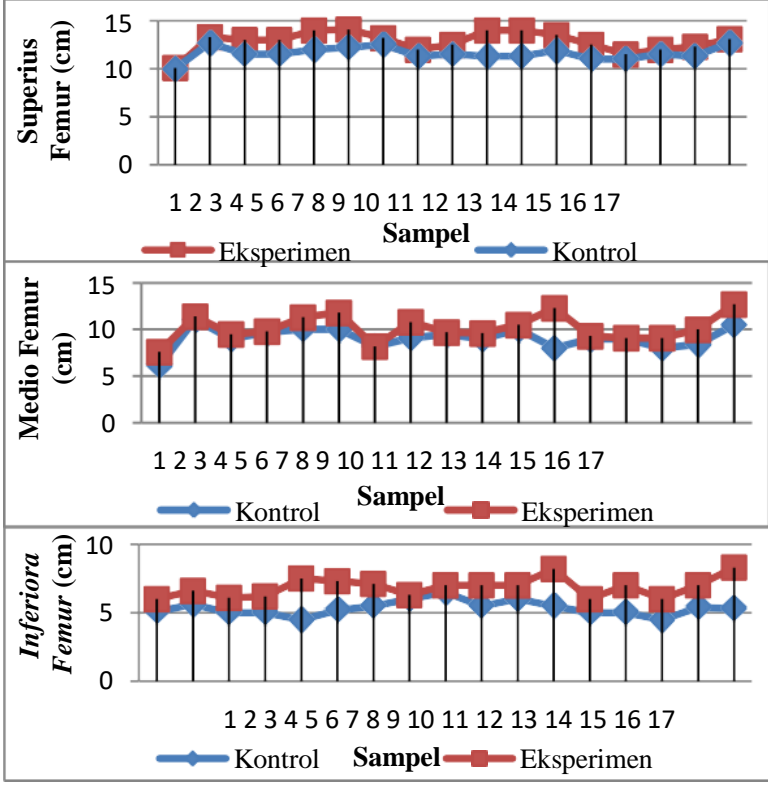

Gambar 3-2 Grafik Data Hasil Keliling Fgg
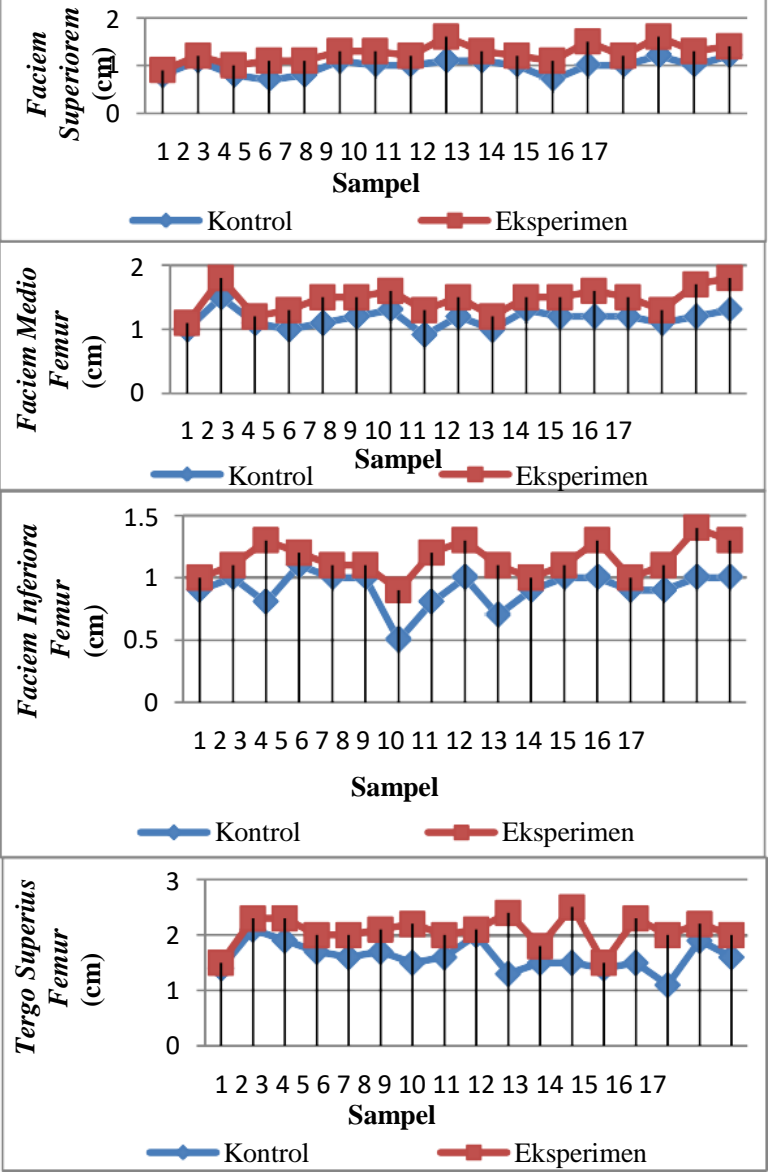
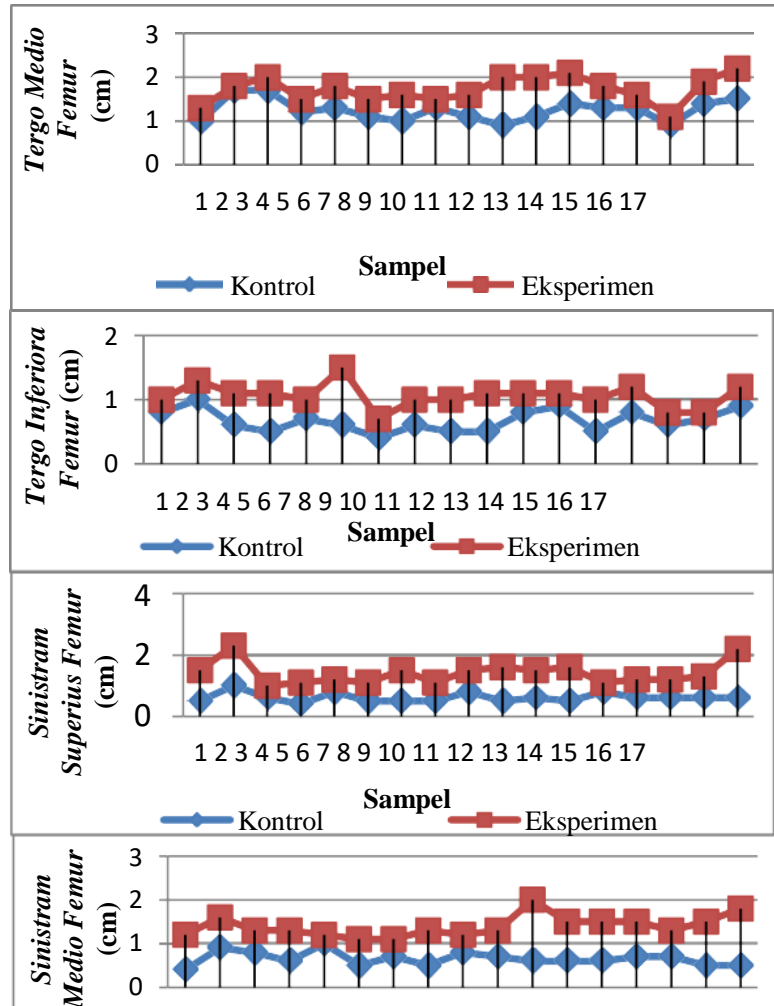

1234567891011121314151617
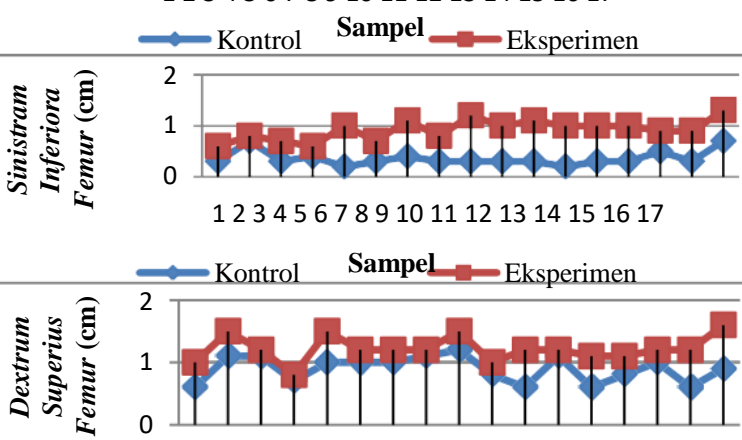

1234567891011121314151617
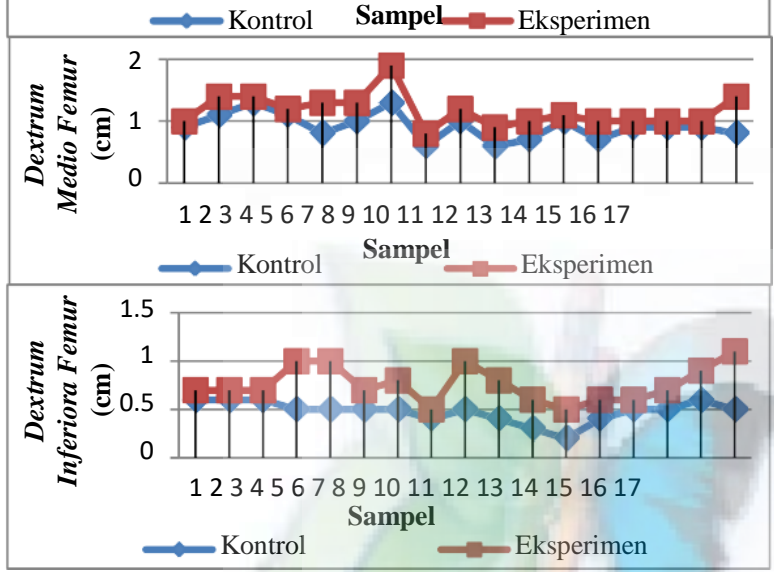

Gambar 3-3 Grafik Data Hasil Tebal Fgg

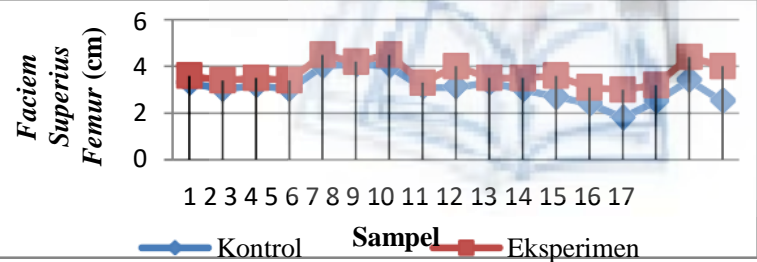



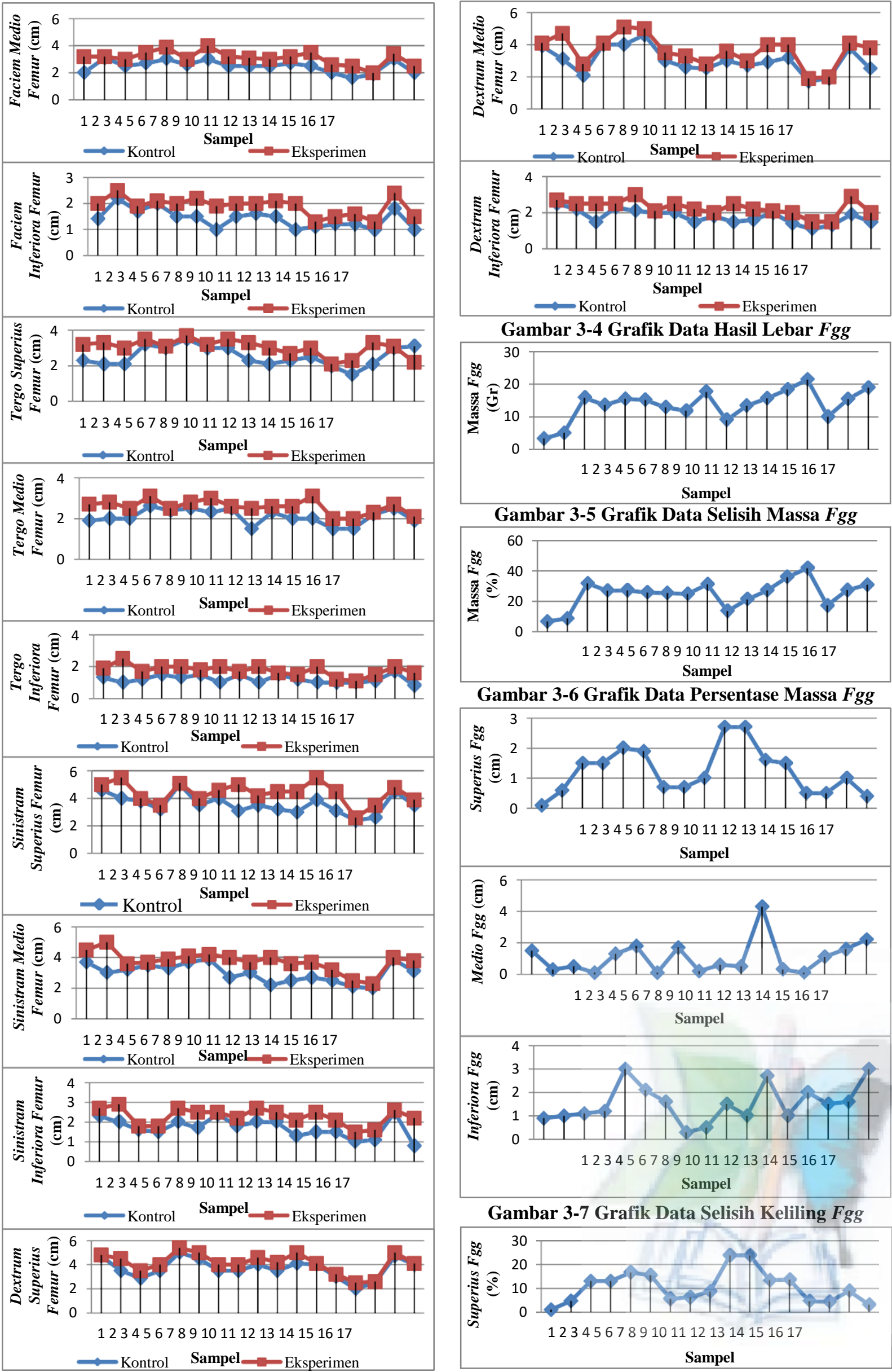

Gambar 3-6 Grafik Data Persentase Massa Fgg
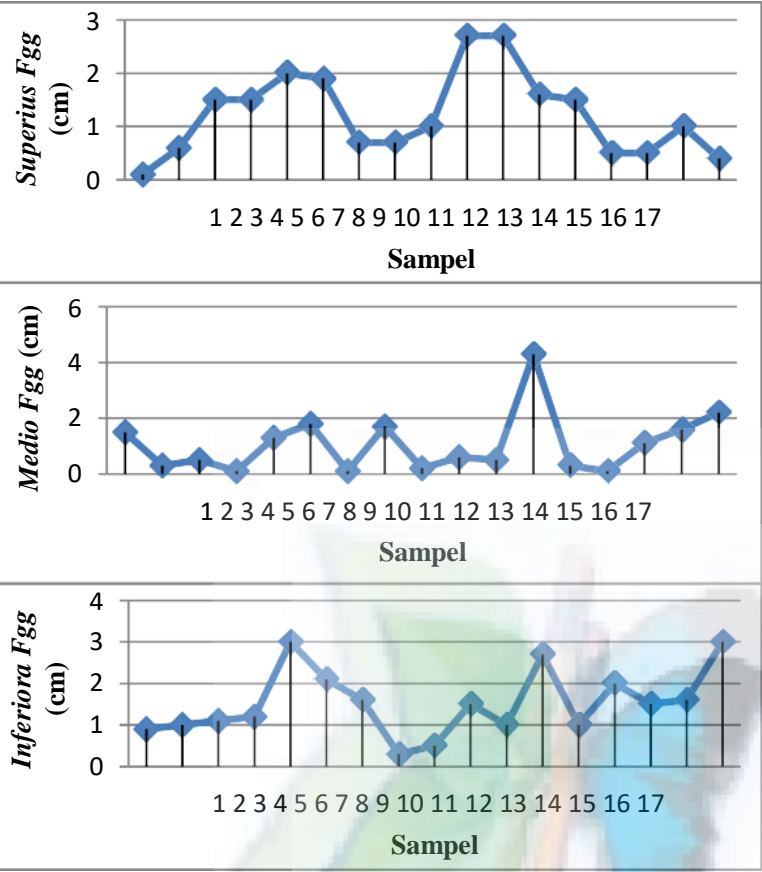

Gambar 3-7 Grafik Data Selisih Keliling Fgg

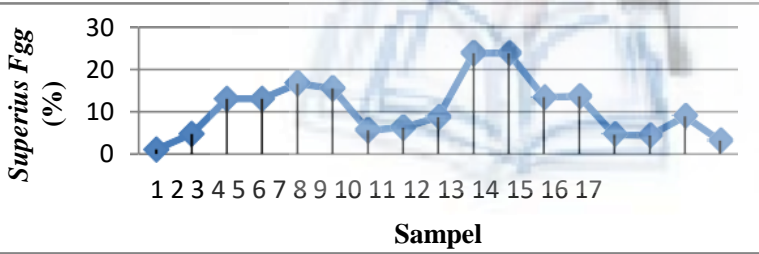




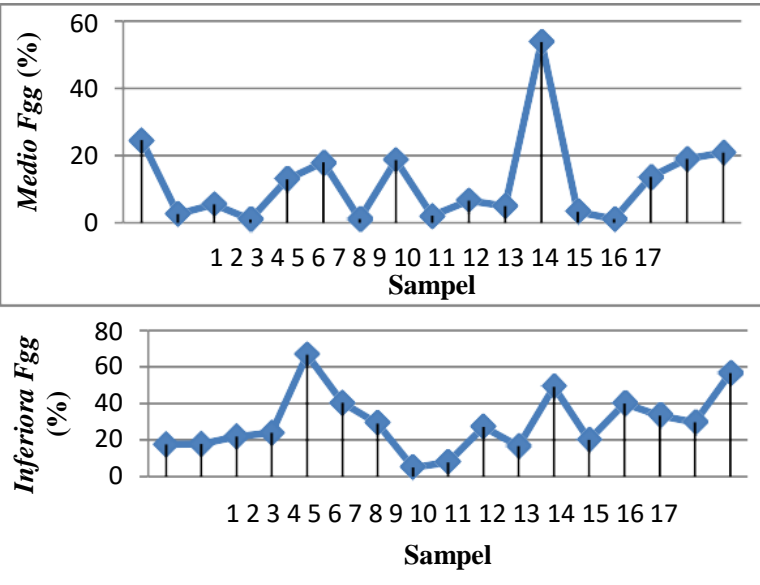

Gambar 3-8 Grafik Data Persentase Fgg
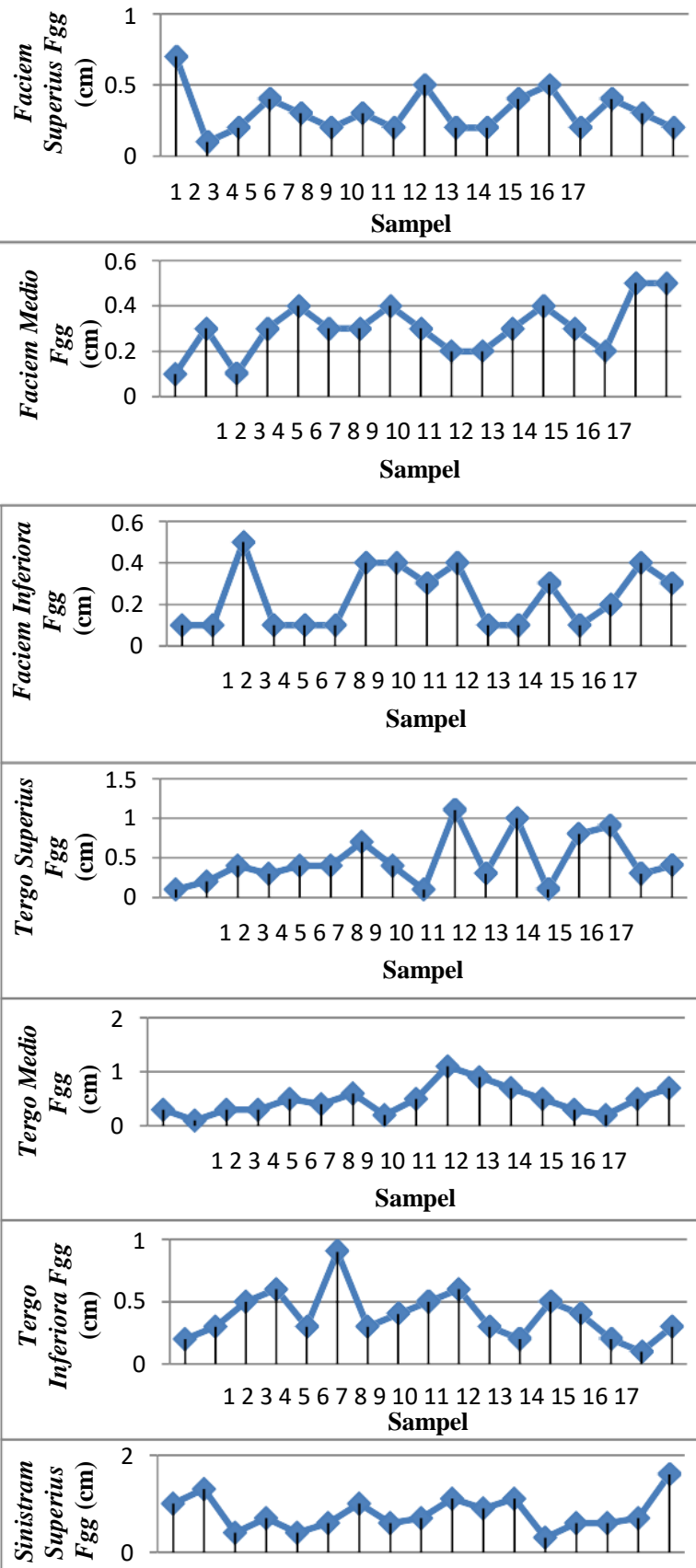

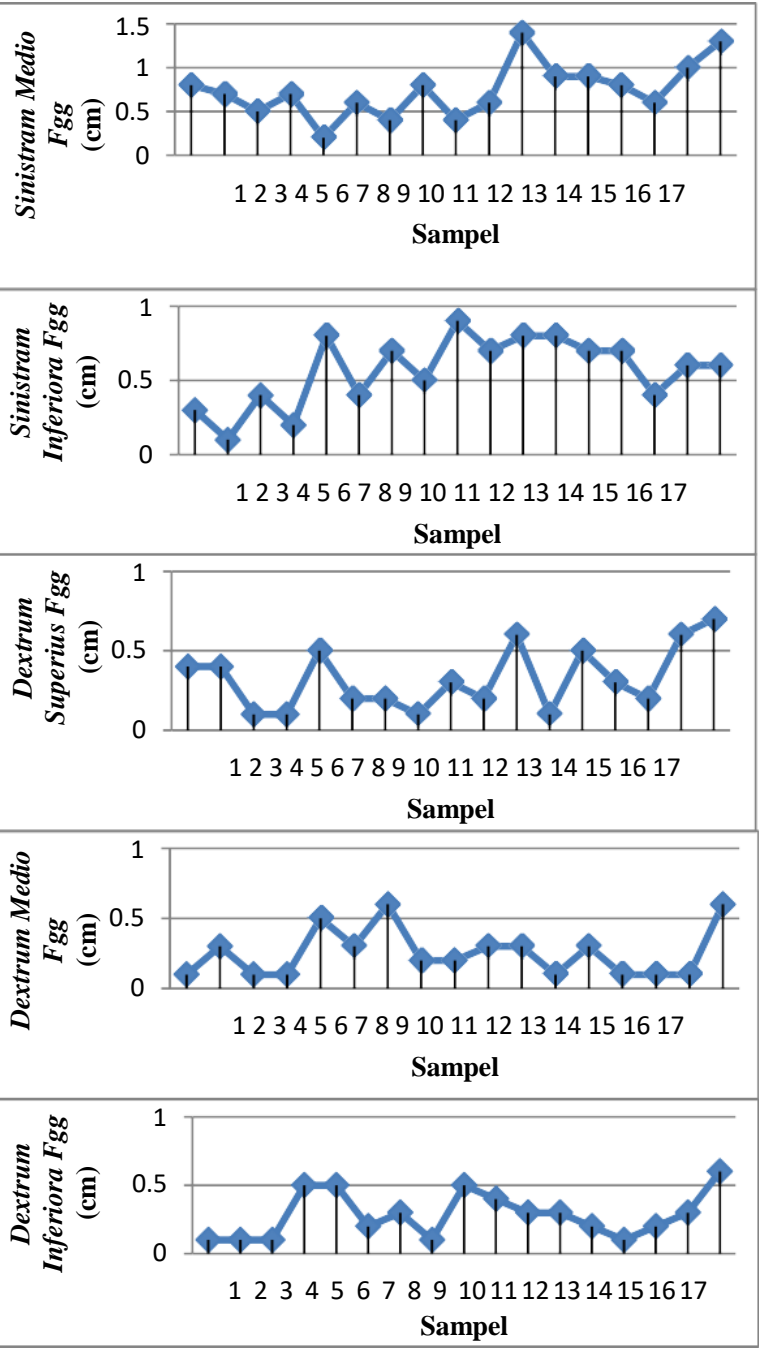

Gambar 3-9 Grafik Data Selisih Tebal Fgg
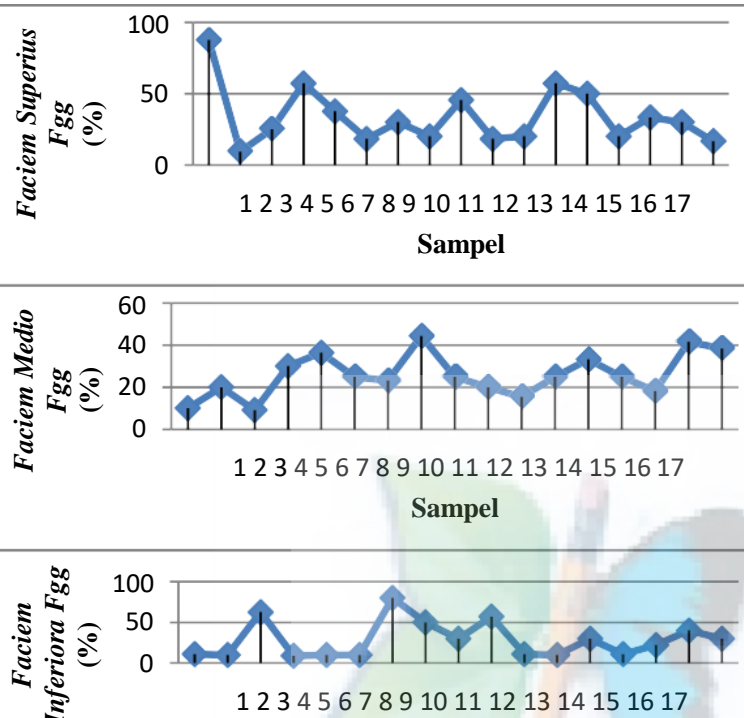

Sampel

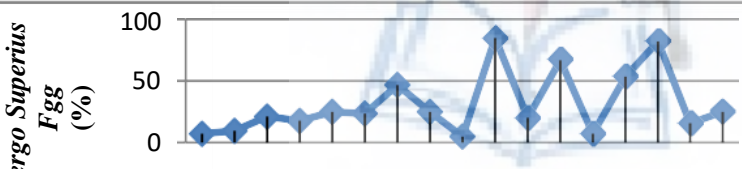

1234567891011121314151617

Sampel 

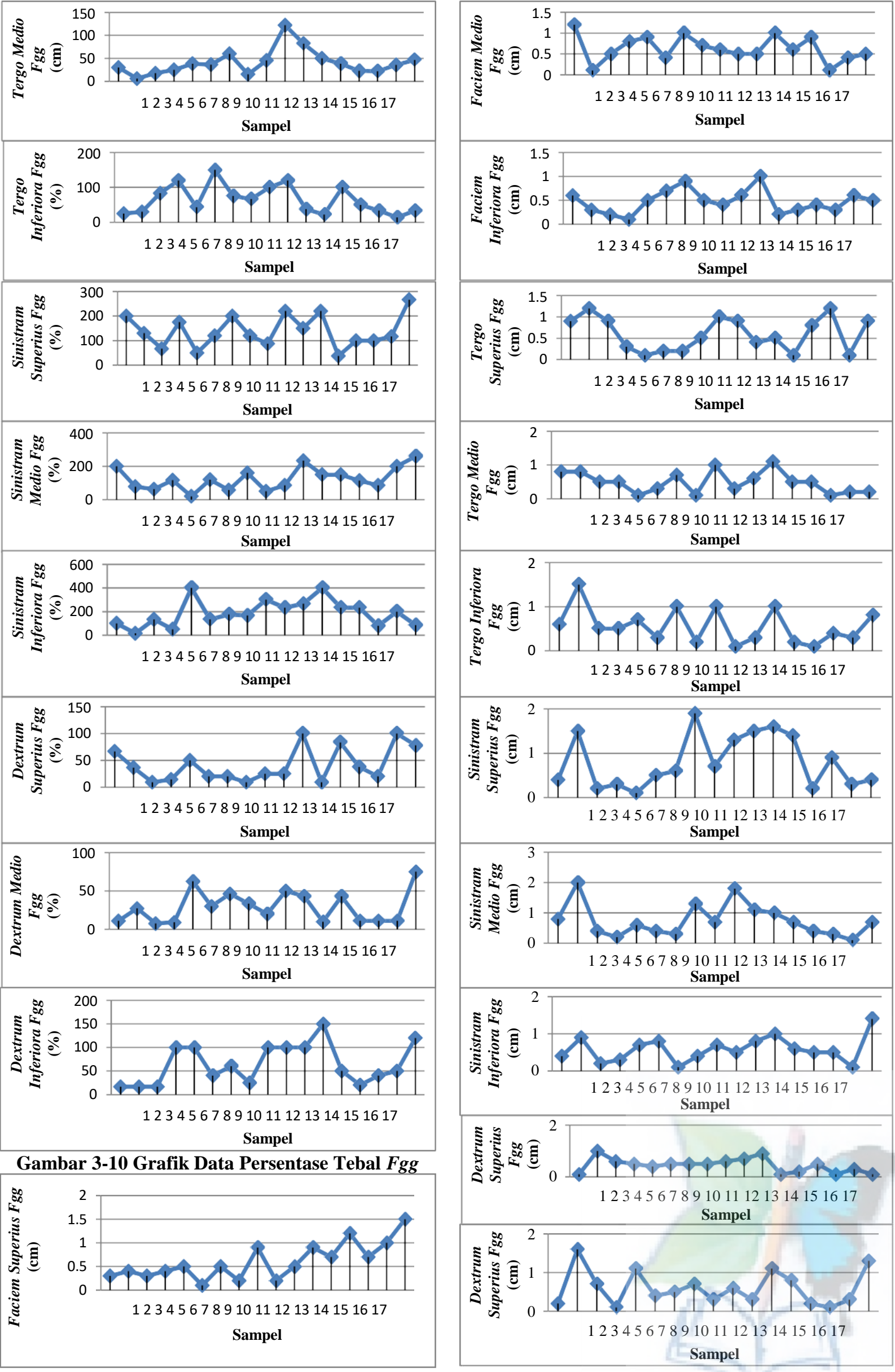


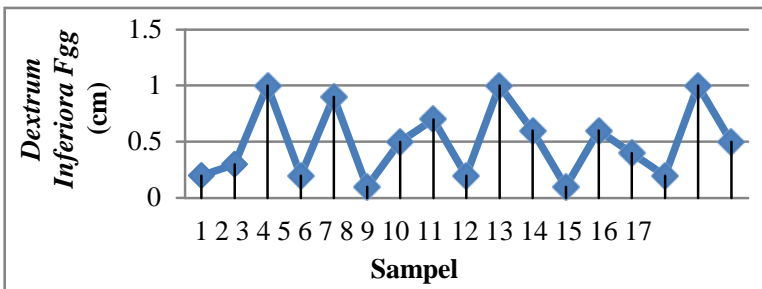

Gambar 3-11 Grafik Data Selisih Lebar Fgg

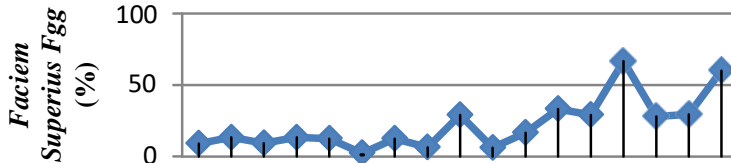

1234567891011121314151617 Sampel

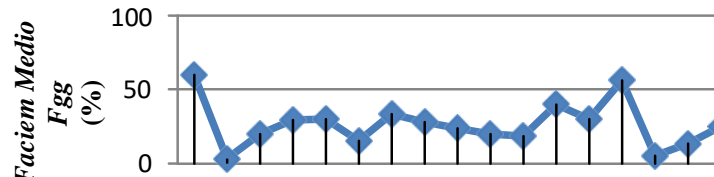

1234567891011121314151617

Sampel

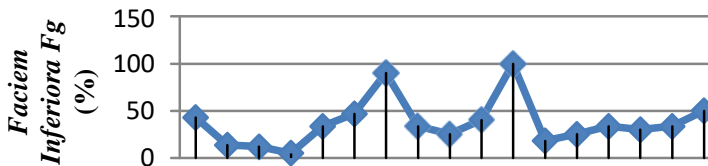

1234567891011121314151617 Sampel
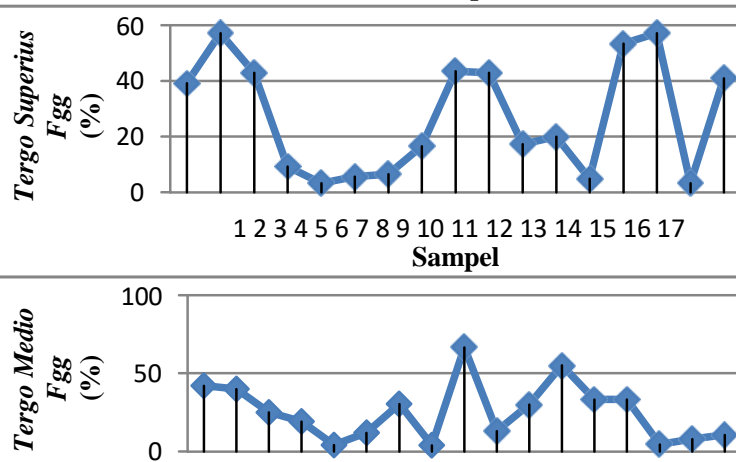

1234567891011121314151617 Sampel
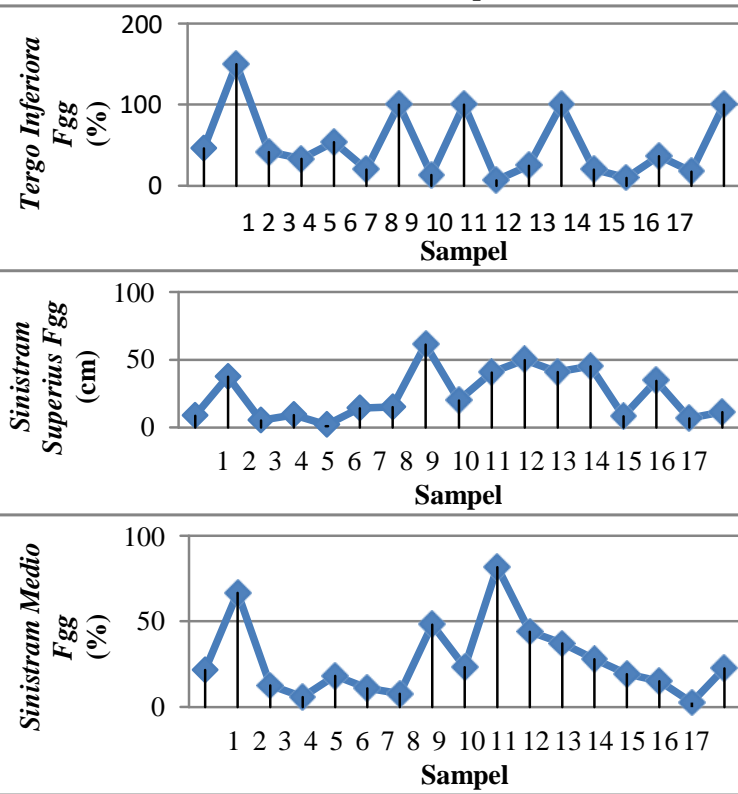

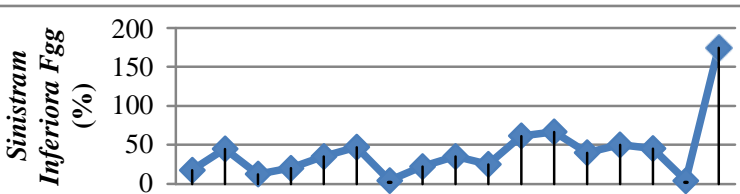

1234567891011121314151617

Sampel

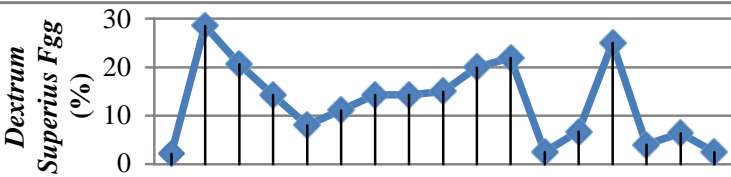

1234567891011121314151617 Sampel
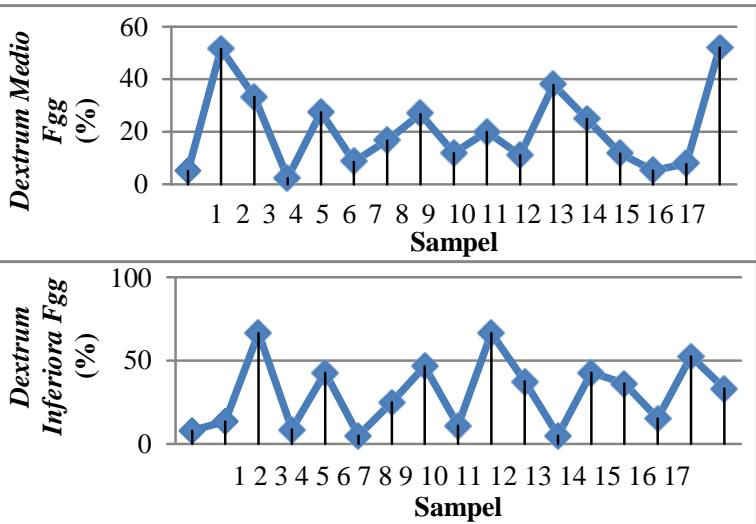

Gambar 3-12 Grafik Data Persentase Lebar Fgg

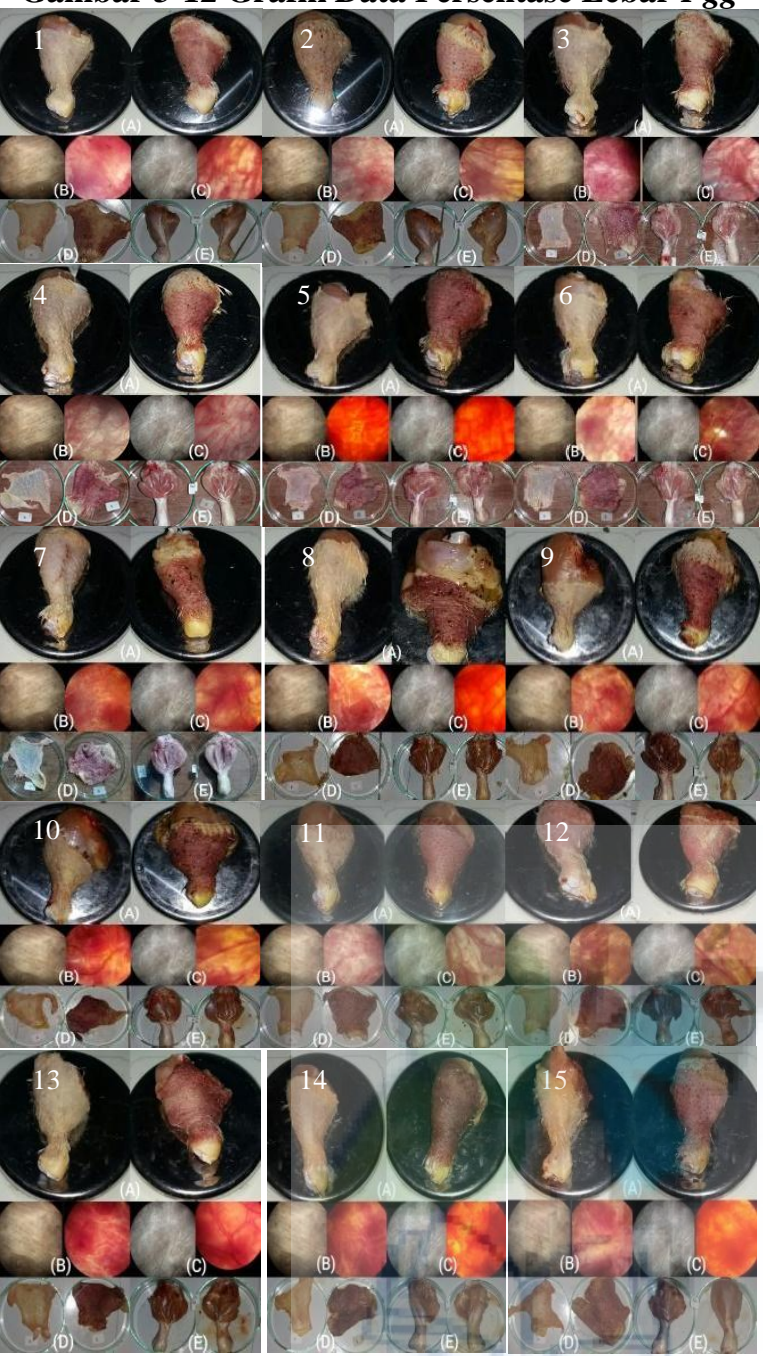




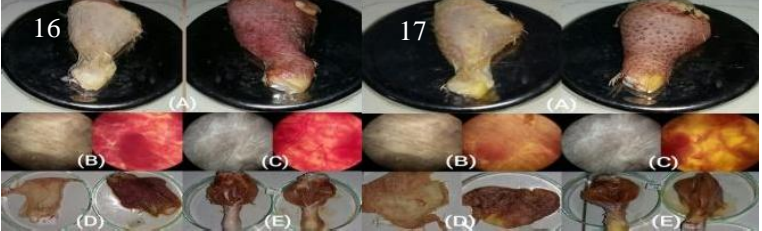

Gambar 3-13 Perbandingan Perubahan Sampel 1 Sampel 17 (A) Fgg, (B) penampang kulit bagian luar, (C) Penampang kulit bagian dalam, (D) Kulit Fgg, (E) Daging Fgg

Hasil perhitungan selisih dan persentase menunjukan bahwa massa, keliling, tebal dan lebar antara sampel eksperimen dan sampel kontrol dari Fgg ini tidak sama atau mengalami perubahan. Hal ini terjadi karena adanya aktivitas dari daun Smilax $S p$ yang menyebabkan edemi (16), terbukti dengan adanya perubahan ukuran massa, keliling, tebal dan lebar FE yang lebih besar dari pada FK serta perubahan lainnya seperti warna kulit, tekstur dan warna dagingnya.

Perbandingan massa, keliling, tebal dan lebar antara FE dan FK pada penelitian ini mengalami perubahan yang disebabkan karena adanya edemi dan edemi yang terjadi pada penelitian ini ialah angioedema. Angioedema merupakan edemi yang terjadi pada bagian bawah kulit yang disebabkan oleh makanan ataupun penggunaan obat-obatan tertentu (18), namun peningkatan perubahannya bervariasi atau mengalami pasang surut mulai dari S1 hingga S17. Hal ini terjadi karena tingkat konsentrasi yang diberikan dan berat setiap sampelnya berbeda - beda serta suatu zat yang memiliki sifat interval terhadap tingkat konsentrasi yang ditentukan (19).

Edemi juga terjadi karena Smilax $S p$ memiliki kandungan zat yang menyebabkan inflamasi sehingga terjadi pembengkakan (16). Inflamasi atau peradangan merupakan salah satu bentuk respon tubuh terhadap cedera, infeksi maupun iritasi yang ditandai dengan munculnya kemerahan, panas, bengkak, sakit dan terjadinya gangguan fungsi tubuh (20). Inflamasi juga dapat terjadi karena rangsangan berbahaya dari zat - zat beracun (21). Edemi yang terjadi pada S1 hingga S17 dalam penelitian ini merupakan hasil peningkatan cairan dari pembuluh darah yang melebar dan permeabel ke dalam jaringan disekitarnya. Selain itu edemi juga diikuti dengan adanya sensasi panas yang terjadi karena peningkatan pergerakan darah melalui pembuluh darah ke bagian ekstremitas yang diinginkan. Sensasi panas tersebut juga menyebabkan bagian kulit Fgg melepuh dan mengakibatkan terjadinya penumpukan lemak pada permukaan atas kulit bagian dalam pada Fgg (16).

Warna kulit FE pada penelitian ini juga mengalami perubahan warna menjadi B22222 atau kemerahan sebagai akibat dari adanya penambahan jumlah eritrosit pada daerah yang dialami dan nyeri atau sakit yang disebabkan oleh efek langsung dari kerusakan akibat inflamasi itu sendiri. Selain itu Gallus gallus domesticus pada penelitian ini juga mengalami gangguan fungsi tubuh yang ditandai dengan ketidaksempurnaannya dalam bergerak karena mengalami kehilangan mobilitas sederhana pada bagian tubuhnya yang mengalami inflamasi (22).

Pada penelitian ini juga terdapat cairan seperti lendir berwarna FFFFE0 yang keluar dari jaringan subkutan atau jaringan bawah kulit, dimana jaringan tersebut merupakan lapisan lemak yang letaknya hanya beberapa milimeter dibawah jaringan dermis (23). Cairan tersebut ada karena terjadi penumpukan pada bagian pembuluh darah dan penumpukan cairan tersebut juga menyebabkan terjadinya tekanan hingga mengakibatkan terjadinya pemecahan pembuluh darah pada bagian kulitnya mulai sampel 6 hingga sampel 17 (24).

FE pada penelitian ini juga mengalami pembesaran pada bagian pori - pori kulit. Pembesaran pori - pori ini mirip dengan yang terjadi pada kulit wajah, penyebabnya ialah karena adanya peningkatan ekskresi pada bagian kelenjar minyak, penurunan kemampuan pori - pori untuk kembali ke posisi semula dan terjadinya peningkatan volume pada folikel rambut (25). Selain itu dagingnya juga mengalami perubahan warna menjadi FAFAD2 akibat adanya aktivitas panas yang dikeluarkan oleh Smilax $S p$ tersebut.

Smilax juga mengandung steroidal saponin yang tinggi dan melimpah (26), dimana kandungan tersebut memiliki beberapa aktivitas biologi salah satunya yaitu sebagai anti inflamasi (27). Penelitian yang dilakukan oleh Hirota berbeda dengan penelitian ini karena spesies yang digunakan ialah Smilax Larvata sedangkan pada penelitian ini menggunakan Smilax Sp. Ini membuktikan bahwa tanaman Smilax $S p$ ini mengandung senyawa lain selain senyawa yang terkandung dalam Smilax Larvata sehingga menyebabkan edemi dan inflamasi.

Edemi yang terjadi pada penelitian ini hampir setengah hingga 4 kali lipat dimana persentase massanya terbesarnya menunjukan $41,66 \%$, kelilingnya $66,67 \%$, tebalnya $400 \%$ dan lebarnya $175 \%$ sedangkan hasil edemi yang dialami oleh wanita hamil pada umumnya mencapai $67 \%$ dan bagian tubuh yang sering mengalami edemi ialah bagian tungkai bawah kaki sebesar 49\% (28).

\section{KESIMPULAN}

Berdasarkan hasil penelitian yang telah ada, maka dapat disimpulkan bahwa aktivitas Smilax $S p$ dapat menyebabkan edemi pada Fgg. Perbedaan konsentrasi Smilax $S p$ menyebabkan tingkat perubahan edemi yang terjadi pada Fgg mengalami variasi pasang surut sehingga semakin tinggi tingkat konsentrasi Smilax Sp yang diberikan pada Fgg maka akan semakin besar pula efek yang terjadi pada Fgg tersebut. Edemi juga diikuti dengan terjadinya perubahan warna pada kulit dengan kode warna B22222, kulit menjadi lebih berkerut, penumpukan lemak pada permukaan kulit atas bagian dalam, pori pori kulit menjadi lebih besar, iritasi hingga terjadi pemecahan pembuluh darah pada bagian kulit, terdapat cairan dengan kode warna FFFFE0 yang 
keluar dari jaringan subkutannya serta terjadi sedikit perubahan warna pada dagingnya dengan kode warna FAFAD2. Edemi pada penelitian ini memiliki persentase massanya tertinggi sebesar 41,66\%, kelilingnya $66,67 \%$, tebalnya $400 \%$ dan lebarnya $175 \%$.

\section{DAFTAR PUSTAKA}

1. Study On Natural Medical Chemistry and New Drug Development. Shiq.W, et al. 2010, Chin Tradit Herb Drugs, hal. 41 : 1583-1589.

2. The Value Of Plants Used In Traditional Medicine For Drug Discovery. Fabricant D.S., Farnsworth N.R. 2001, Environ Health Perspect, hal. 109 : 69 75.

3. Drug Discovery From Medicinal Plants. Balunasa MJ, et al. 2005, Life Sciences, hal. 78 : 431-441.

4. The Role Of Natural Product Chemistry In Drug Discovery. MS, Butler. 2004, Journal Of Natural Product, hal. 67 : 2141-2153.

5. Herbal Medicine Today: Clinical and Research Issues. Gori, et al. 2007, Original Article, hal. $37-$ 40.

6. Kekinian Keanekaragaman Hayati Indonesia. Widjaja, et al. 2014, Jakarta : LIPI Press.

7. Common Forest Threes Of Irian Jaya Papua Indonesia. Jhons. 1997, Royal Botanical Garden, Kew Inggris.

8. Laporan Rapid Asessment Program (RAP) CI-IP dan Uncen di Yongsu, Jayapura. De'Fretes. 2000, Conservation International-Indonesia Program Jayapura.

9. Buah Merah: potensi dan manfaatnya sebagai antioksidan. [Red Fruit (Pandanus conoideus): potential and benefits in terms of antioxidants]. Martosupomo, et al. 2009, Jurnal Tumbuhan Obat Indonesia, hal. 42-48.

10. GC/MS profiling, in vitro antioxidant, antimicrobial and haemolytic activities of Smilax macrophylla leaves. Zubair M, et al. 2013, Arabian J Chem.

11. New furostanol saponins from Smilax aspera $L$. and their in vitro cytotoxicity. Fitoterapia. Ivanova A, et al. 2011, hal. 82 : 282-287.

12. Preliminary phytochemical analysis, antimicrobial and antioxidant activity of Smilax zeylanica $L$. (Smilacaceae). Dhanya.S, et al. 2018, Journal of Drug Delivery and Therapeutics, hal. 237-243.

13. Phenolic Compounds in Genus Smilax (Sarsaparilla). Raul C.S, et al . 2017, American Journal, hal. 233-260.

14. Smilax (Smilacaceae) from the miocene of western eurasia with caribbean biogeographic affinities. Denk. T, et al . 2015, American Journal Of Botany, hal. 423-438.

15. Phylogenetic Analysis and Molecular Identification of Canar (Smilax Spp) in Java, Indonesia Based on DNA Barcoding Analysis. Sulistyaningsih. L.D, et al. 2018, Biodiversitas, hal. 364-368.
16. Identifikasi Proses Edemi Efek Dari Smilax Sp. Tualeka. M, et al. 2019, Biolearning Journal, hal. $1-7$.

17. Solso, et al. Cognitive Psychologi. New York : Pearson, 2005.

18. Angioedema. Kaplan A.P. 2008, WAO Journal, hal. 103-113.

19. Concentration-Effect Relationships and Implications for Trough-to-Peak Ratio . Meredith. P. A dan Elliott. H. L . 1996, American Journa, hal. 66-70.

20. Dampening inflammation. Henson PM. 2005, Nat Immunol, hal. 6:1179-81

21. Inflammation 2010: new adventures of an old. Medzhitov R. 2010, Cell, hal. 140:771-776.

22. The Journal of Inflammation. Punchard. N. A, et al. 2004, Journal of Inflammation, hal. 1-4.

23. Glycative stress and anti-aging. Benítez JM, \& Montáns FJ. 2017, The mechanical behavior of skin: Structures and models for the finite element analysis, hal. 75-107.

24. Edema: a silent but important factor. Villeco, JP. 2012, J Hand Ther, hal. 153-162.

25. Facial Pores: Definition, Causes, and Treatment Options. Lee SJ, et al. 2016, Dermatol surg, hal. 85-277.

26. Steroidal Saponins from the Roots of Smilax sp. Challinor VL, et al. . 2012, Structure and Bioactivity Steroids, hal. 504-511.

27. Larvicide And Antifungal Activities of Sarsaparilla (Smilax Larvata) Extracts. Hirota.B.C.K, et al. 2015, International Journal of Pharmacy and Pharmaceutical Sciences, hal. 308311.

28. Frequency of Lower Extremity Edema during. Tanveer, F et al. 2017, hal. 41-43. 